\title{
Does socioemotional wealth matter for competitive advantage? A case of Polish family businesses
}

\author{
Katarzyna Bratnicka-Myśliwiec ${ }^{1}$ \\ Martyna Wronka-Pośpiech ${ }^{2}$ \\ Tomasz Ingram ${ }^{3}$
}

\begin{abstract}
A growing body of research is concerned with how family businesses achieve competitive advantage, yet unique qualities that distinguish family firms and nonfamily firms are sometimes overlooked. In our study, we argue that socioemotional wealth (SEW) may trigger or limit family firms' strategic initiatives that ultimately shape their competitive advantage. Therefore, in our study of 193 Polish family firms, we investigate how (SEW) and a firm's competitive advantage are associated with a family firm context. Our research results reveal that, indeed, (SEW) and competitive advantage are partially associated and SEW can be regarded as an important strategic antecedent to firm performance.
\end{abstract}

Keywords: family business, (SEW), competitive advantage.

\section{INTRODUCTION}

In recent years, a growing interest in family entrepreneurship can be observed. The popularity of family businesses is a consequence of the significant role they play in the economy, but also the fact that they have

1 Katarzyna Bratnicka-Myśliwiec, Ph.D., Assistant Professor, University of Economics in Katowice, Faculty of Economics, Department of Entrepreneurship and Management Innovation, ul. 1-go Maja 50, 40-287 Katowice, Poland, e-mail: katarzyna.bratnicka@ue.katowice.pl (ORCID ID 0000-0002-3761-0641)

2 Martyna Wronka-Pośpiech, Ph.D., Assistant Professor, University of Economics in Katowice, Faculty of Economics, Department of Entrepreneurship and Management Innovation, ul. 1-go Maja 50, 40-287 Katowice, Poland, e-mail: martyna.wronka-pospiech@ue.katowice.pl (ORCID ID 0000-0001-9240-6670)

3 Tomasz Ingram, Ph.D., Associate Professor, University of Economics in Katowice, Faculty of Economics, Department of Entrepreneurship and Management Innovation, ul. 1-go Maja 50, 40-287 Katowice, Poland, e-mail: tomasz.ingram@ue.katowice.pl (ORCID ID 0000-0002-4161-6261) 
coped relatively well with the effects of the economic crisis. The reasons for that are associated with the specific culture of family entrepreneurship, expressed in the sphere of values, and reflected in the relationship within teams and the ways of managing these entities. Therefore, efforts made by both management theoreticians and practitioners, aimed at identifying the determinants of family firms' competitiveness and understanding the determinants of their functioning, are not surprising. Nowadays, researchers still face theoretical and empirical challenges stemming from the intensive interpersonal relations between different stakeholders and those pursuing non-financial goals, which are not typically found in non-family businesses (Evert, Martin, McLeod, \& Payne, 2015; Reilly \& Jones III, 2017). The nuanced insights into the complexity of the dynamics, due to the blurred boundaries between family and business, are relatively underdeveloped. Indeed, we need both family business specific theories, as well as valid measurement instruments relevant to family business research.

This study aims at complementing and extending existing research on family firm competitive advantage by taking a SEW perspective. It is based on the idea that family firms can be competitive while still maintaining a strong family character (Chrisman \& Patel, 2012). Based on these premises, this study attempts to extend current theory on family firms in two major respects. First, the study complements prior empirical studies on how family firms achieve competitive advantage. In particular, this study aims at extending and refining existing theory as to how family firms can best accommodate and leverage their attributes SEW, in particular in order to achieve competitive advantage. Secondly, our study attempts to extend current theory on SEW as a construct that is linked to competitive advantage in family business settings. This is important because of wired-in family forces for SEW maintenance.

\section{LITERATURE BACKGROUND}

\section{SEW and competitive advantage}

This study is drawn up in the convention of strategic management, which focuses on the organization (in particular on the enterprise) as the basic level of analysis and recognizes the diversity of the organization in terms of efficiency, that is in the area of creating and capturing values (Durand, Grant, $\&$ Madsen, 2017). From among a variety of possible approaches, a resourcebased approach was chosen that puts emphasis on the strategically valuable resources and abilities of the enterprise being a source of competitive 
advantage. Research attention was focused on the SEW, which is an important strategic resource.

Family businesses are defined as those in which many members of the same family are involved as owners or managers, either now and in time (Miller, Le Breton-Miller, Lester, \& Cannella, 2007). The family is a specific social group related to marriage, biology or adoption, including people also connected with affection, commitment, dependence and cooperation (Rothausen, 1999).

Unlike the non-family firms, family businesses have some unique qualities that can lead to competitive advantage. We argue that the SEW theory is suited to examining deeply the kind of strategic consequences of specific features of family firms. In our paper, we define that SEW (hereafter, SEW) refers to an "all-encompassing approach that captures the affective endowment of family owners" (Berrone, Cruz, \& Gomez-Mejia, 2012). In other words, SEW is concerned with attributes of the firm that bear the family's affective endowments (Gomez-Mejia, Hynes, Nunez-Nickel, \& Moyano-Fuentes, 2007).

Research has shown that the SEW perspective offers a conceptual framework to view the complex and dynamic interplay of economic and noneconomic factors (Chrisman, Chua, De Massis, Frattini \& Wright, 2015; Miller \& Le Breton-Miller, 2014). From SEW considerations, which emphasize that they take precedence over the assessment of economic benefits and costs (Gomez-Mejia et al., 2007), changes in behavioral decision-making processes might result in declining power to pursue the family agenda (Leitterstorf \& Rau, 2014). Similar dynamics have been documented in other settings such as avoiding acquisitions that threaten the preservation of existing stock of SEW (Miller, Le Breton-Miller, \& Lester, 2010). Furthermore, the introduction of new ways of working and, probably, human resource, is perceived as a potential threat to family stability, specifically to affinity-related dimensions, namely family identity, social bonds, and emotional attachment (GomezMejia, Makri, \& Lazzara-Kitana, 2010). Meanwhile, in SEW case, developments with regards to new, discontinuous technology adoption are inhibited as a potential dilution of family control (Konig, Kammerlander, \& Enders, 2013). Using similar, family-ownership logic, Souder, Zaheer, Sapienza, and Ranucci (2017) theorize and demonstrate a tendency to perceive new technology as potential erosion of SEW, mainly from identity and family influence aspects. Drawing on this perspective, we argue that SEW may trigger or limit family firms' strategic initiatives that ultimately shape their competitive advantage. In general, findings indicate that the boundaries between business and family are blurred, ultimately affecting how family firms perform their strategic activity (Duran, Kammerlander, van Essen \& Zellweger, 2016). 
The consideration of SEW is important because forming SEW appears critical to firm performance - but it is not always so (Bettinelli, Sciascia, Randerson, \& Fayolle, 2017). Berrone et al. (2012) significantly contribute to the SEW literature by showing that SEW, as a latent explanatory construct, has five dimensions, namely: (1) family control and influence, (2) identification of family members with the firm, (3) binding social ties, (4) emotional attachment of family members, and (5) renewal of family bonds to the firm through dynastic succession. According to such a conceptualization of SEW, the first dimension refers to exercising current family control, which depends on family members' power to control key strategic decisions both formally (e.g., a family member being the CEO or owner) and informally influencing decision-making processes. The second dimension connotes a close linkage between the reputation of family and firm, which provides a sense of identity that is also visible in a broader social context. The next dimension relates to the social relationships of the family firm, its family members, its internal as well as external stakeholders, which create social capital as a potential for gaining access to desirable resources and experiences. The fourth dimension is associated with shared emotions, heritage, jointly experienced events, and responsibility for the long-term viability of family firms that become a source of affective needs satisfaction (e.g., belonging, security). The fifth dimension, in turn, characterizes a tendency to keep the family under the family's control over multiple generations, and therefore protect the family's wealth and value. These scholars have also labeled the operationalization of this set of dimensions as the FIBER scale, which is intended to measure socioemotional endowment across family firms. Additionally, they demonstrate how the tendency to preserve SEW as a decision criterion, strengthens strategic choices that carry a significant financial risk. Lastly, they explain why the studies with regards to effecting firm performance have been inconclusive and ambiguous.

The desire to preserve SEW potentially leads to specific strategic orientations (De Massis, Kotlar, Chua, \& Chrisman, 2014). Duran et al. (2016) in their meta-analysis recognize that family firms engage in innovation less than their non-family counterparts. Other scholars have also examined SEW within entrepreneurship literature, recognizing that corporate entrepreneurship allows the firm to considerably improve its competitive advantage (Corbett, Covin, O'Connor, \& Tucci, 2013). Similarly, innovations enhance their competitive advantage (Hayton \& Kelley, 2006).

In terms of family control and influence, earlier findings focus on the indirect effects of this dimension on competitive advantage. In particular, a high proportion of family members in top management lead to a negative relationship between innovation orientation and new product portfolio performance (Kraiczy, Hack, \& Kellermanns, 2014). Chrisman and Patel 
(2012) demonstrate that family ownership is negatively related to research and development spending. This is because family owners perceive such investments as risky and might threaten their influence in the firm. In contrast to these findings, Hauck and Prugl (2015) show that the effects of family involvement on a willingness to innovate are ambiguous and even conflicting. There is also evidence that family involvement in the board of directors influences entrepreneurial orientation according to an inverted U-shaped relationship (Bauweraerts \& Colot, 2017). Lee and Chu (2017) have also documented that entrepreneurial orientation magnifies family firm performance when family control is very active.

Scholars have also highlighted how the second dimension of SEW influences organizational outcomes. Stevens, Kid well and Sprague (2015) draw on the basic idea that family owners' identity is strictly connected with the firm. In consequence, the boundaries between the reputation of family and firm fade (Leitterstorf \& Rau, 2014). Shepherd and Haynie (2009) uncovered that an appropriate level of family business identity fit strengthens the tendency to entrepreneurial activities. Therefore, family member's identification with the firm leads to conservative orientation and innovation aversion (GomezMejia et al., 2007). Some family business scholars demonstrated how strong identification limits firm growth (Anderson \& Reeb, 2003; Jones, Makri, \& Gomez-Mejia, 2008).

Research has also shown how the binding-ties dimension is related to family firm innovation, and in consequence to competitive advantage (De Massis, Kotlar, Frattinin, Chrisman \& Nordqvist, 2016). Moreover, strong social relationships between the family firm, family members, and internal and external stakeholders create social capital and knowledge networks (Uhlaner, 2006), which, in turn, contribute to a greater access to resource and experiences (Miller, Le Breton-Miller, \& Scholnick, 2008). This opens up the potential for information sharing (Gomez-Mejia et al., 2007) and ultimately results in the ability to innovate (Spriggs, Yu, Deeds, \& Sorenson, 2013). As Mohr and Puck (2013) also show that good relationships with different stakeholders enhance competitive advantage. In general, family firms' social capital positively impacts performance in a variety of settings (Sorenson, Goodpaster, Hedberg, \& Yu, 2009).

Emotional attachment to the actual organization, to which Fan and Zietsma (2017) refer, can encourage specific action as a driver of competitive advantage. Some works identify the competitive advantage effects of emotional attachment. Welsh, Memili, Rosplock, Roure and Segurado (2013) noted that family emotional attachment strengthens family office entrepreneurial orientation. In this vein, the existence of a positive association of affective commitment and family engagement with entrepreneurial 
behaviors is observed (Salvato, Chirico, \& Sharma, 2010). In fact, strong emotional attachment supports a sense of responsibility for the viability of a family firm (Miller et al., 2008; Lumpkin, Brigham, \& Moss, 2010).

Last, regarding the renewal of family bonds to the firm through dynastic succession, Lumpkin et al. (2010) theoretically explain the positive impact of the long-term orientation of family firms on proactiveness, innovativeness and autonomy, while it negatively influences risk-taking and competitive aggressiveness. The focus on transgenerational succession results in longterm decisions (Levenburg, Schawrz, \& Almallah, 2002) and a willingness to invest in a firm's growth (Classen, Carree, Van Gils, \& Peters, 2014). Eddleston, Kellermans and Zellweger (2012) confirm the positive influence of long-term orientation on corporate entrepreneurship. Gomez-Mejia, Campbell, Marin, Makri, Sirmon, and Hoskinsson's (2014) findings contradict the literature - in which the advantages of SEW are emphasized - and reveal that family firms are oriented on high financial wealth rather than on a long-term perspective and an agreement on a later pay-off. The longterm orientation of top management can, however, act as an innovation driver by raising the tendency to experimentation and extending the time for creativity (Kammerlander \& Ganter, 2015). Their results also shed light on how socioemotional goals can reinforce the achievement of economic goals. Other studies report that a family firm's predisposition to carry the firm onto the next generation (Mahto, Ahluwalia, \& Khanin, 2014) is associated with more risk aversion (Craig, Pohjola, Kraus, \& Jensen, 2014). Contrary to what we would have believed from the socioemotional negative-effect literature, some scholars find positive consequences of unique family heritage that intensify the innovation process (Classen et al., 2014). In other words, to preserve a firm's wealth for the next generation, family firms need to be innovative (Cassia, De Massis, \& Pizzurno, 2011).

In sum, innovation is a key driver of family firm continuity (Filser, Brem, Gast, Kraus, \& Calabrò, 2016). By combining the abovementioned arguments, we have shown that SEW may both enable and constrain family firm performance, as a result of simultaneously providing long-term orientation, as well as setting in motion risk aversion. As Songini and Gnan (2015) already noted, family firm dynamics is based on the contradiction between protecting the family goals and long-term viability.

The relationships between family business attributes and firm performance are by no means easy to understand. The abovementioned five general points form a strong base on which to posit that SEW influences family firm competitive advantage. They enter into competitive advantage through individual SEW dimensions which activate entrepreneurship and innovation in particular, and so lead to a competitive advantage for the family firm. Although 
previous studies have highlighted and vividly discussed the impacts of SEW on firm performance, it should be remembered that the results are inconclusive (Debicki, Van de Graaff, Randolph, \& Sobczak, 2017). To take an example, the risk of losing the value of SEW leads to specific strategic action that augments its "dark side" by reducing financial performance (O'Boyle, Pollack, \& Rutherford, 2012). In contrast, another possibility is that family firms outperform nonfamily counterparts (Wagner, Block, Miller, Schwens, \& Xi, 2015). Theoretical and empirical ambiguities noted by several scholars have a common strategic perspective (Strike, Berrone, Sapp, \& Congiu, 2015). Indeed, in recent years, appreciation of SEW as an important strategic antecedent to firm performance has increased substantially (Sharma \& Sharma, 2011).

To sum up our literature review, current studies emphasize links between SEW dimensions and competitive advantage. Although previous research is inconclusive, showing different effects of SEW dimensions on competitive advantage (both negative and positive), we posit that there is a clear rationale to link, theoretically, the two constructs. Thus, consistent with our discussion earlier, we elaborated the following hypothesis:

Hypothesis 1. In a family firm context, SEW and a firm's competitive advantage are associated.

\section{RESEARCH METHODS}

\section{Sample}

To test the research hypothesis and verify the created research model, we carried out empirical research on family firms from southern Poland - the Silesian voivodeship. The data were gathered between June and August 2017. The survey was constructed in English, and then we translated the items of original scales into Polish and then translated them back into English. Minor adjustments were made in the process to ensure content similarity of the versions. In the following step, a market research company telephoned 974 randomly-selected small and medium-sized family companies. Respondents were asked three screening questions: (1) Are you an owner of the company and are you willing to participate in a study? (2) Do you consider your company to be a family firm? And (3) Do you or your family own more than $50 \%$ of the company? If the respondent's answers to all the questions were positive a face-to-face interview, based on a questionnaire, was arranged. Next, the dataset was reviewed for incomplete responses, outliers, and uniform responses across all scale items. From the original telephone research sample 
of 974 firms contacted we gathered 211 completed questionnaires, of which 193 were included in the research. These procedures yielded an effective response rate of $19.8 \%$, which is slightly below similar research carried out in a Polish context (see Debicki et al., 2017).

\section{Dependent variables}

Competitiveness of a family business. To measure the competitiveness of a family business, we used a modified, 5-item 7-point Likert scale developed by Antoncic and Hisrich (2001) (alfa Cronbach $=0.835$ ), composed of growth in employment, net sales, volume and market share, and net profit over the past three years in relation to main competitors. Exploratory factor analysis (Kaiser-Meyer-Olkin Measure of Sampling Adequacy $=0.796$; Bartlett's Test of Sphericity - Approx. Chi-Square $=368.308$ with 10 degrees of freedom, significance: $p=0.000$ ), using principal component analysis with Varimax rotation, revealed that a single component - factor explains $60.76 \%$ of the variance and, considering the eigenvalue criteria, we found no support for identifying other factors. All five items loaded to this single factor, with factor loadings varying from 0.714 to 0.825 . Thus, in the following analyses, we considered competitiveness as the unidimensional, latent construct.

\section{Independent variables}

SEW. Congruent with recent calls for distinguishing between dimensions of SEW (Gomez-Mejia, Cruz, Berrone, \& De Castro, 2011), we identify three formative dimensions, which have different antecedents as well as consequences (George, 2011; Sullivan \& Ford, 2010). As a consequence of the results of the exploratory factor analysis (Kaiser-Meyer-Olkin sample adequacy equal to 0.937 , significant Bartlett's test of sphericity at a level below 0.05 , percentage of variance explained equal to 61.7 for four factors), and following Hinkin's (1998) criteria (presented earlier), we eliminated 10 items from the original scale.

The remaining 17 items were subjected to confirmatory factor analysis in Mplus. This analysis confirmed that there are three dimensions, and the model was fitted slightly above the cut-off level for RMSEA $(0.062$, with the cut-off line as 0.06), and with satisfactory CFI and Tucker-Levis Index (TLI) level reaching 0.957 and 0.946 , respectively. Thus, finally for calculations we used three dimensions: family control and identification with the firm (11 items, Cronbach's alpha $=0.947$ ), binding social ties ( 3 items, Cronbach's alpha $=$ 0.675 , that is slightly above the accepted 0.6 level (Drasgow, 1984)), and long 
term emotional attachment (emotional attachment of family members and renewal of family bonds) (3 items, Cronbach's alpha $=0.721$ ). Recent empirical results strongly suggest that the family influence and control dimension yields high levels of family firm noncompliance with corporate governance codes (Kabbach de Castro, Aguilera, \& Crespi-Cladera, 2017). In addition, and by contrast, the identification dimension (image and reputation, in their words) weakens the aforementioned relationship. Drawing on this logic, our core argument is that these two SEW dimensions are closely related and influence family firm strategic behavior. Turning to the interpretation of our results, we propose to name the first factor "family control and identification with a firm." Rotated loadings and questionnaire items are presented in Table 1.

Table 1. Rotated component matrix for SEW

\begin{tabular}{|c|c|c|c|}
\hline \multirow[t]{2}{*}{ Items } & \multicolumn{3}{|c|}{ Component } \\
\hline & $\begin{array}{l}\text { Family } \\
\text { control and } \\
\text { identification } \\
\text { with a firm }\end{array}$ & $\begin{array}{l}\text { Binding } \\
\text { social ties }\end{array}$ & $\begin{array}{l}\text { Emotional } \\
\text { attachment } \\
\text { of family } \\
\text { members }\end{array}$ \\
\hline $\begin{array}{l}\text { 7. Family members have a strong sense of belonging to } \\
\text { my family business }\end{array}$ & .807 & .106 & \\
\hline $\begin{array}{l}\text { 8. Family members feel that the family business's } \\
\text { success is their own success }\end{array}$ & .802 & & \\
\hline $\begin{array}{l}\text { 11. Family members are proud to tell others that we } \\
\text { are part of the family business }\end{array}$ & .785 & & \\
\hline $\begin{array}{l}\text { 9. My family business has a great deal of personal } \\
\text { meaning for family members }\end{array}$ & .770 & & .162 \\
\hline $\begin{array}{l}\text { 3. In my family business, most executive positions are } \\
\text { occupied by family members }\end{array}$ & .768 & .187 & .114 \\
\hline $\begin{array}{l}\text { 6. Preservation of family control and independence are } \\
\text { important goals for my family business }\end{array}$ & .748 & & .149 \\
\hline $\begin{array}{l}\text { 5. The board of directors is mainly composed of family } \\
\text { members }\end{array}$ & .733 & .168 & \\
\hline $\begin{array}{l}\text { 2. In my family business, family members exert control } \\
\text { over the company's strategic decisions }\end{array}$ & .730 & .219 & .111 \\
\hline $\begin{array}{l}\text { 10. Being a member of the family business helps } \\
\text { define who we are }\end{array}$ & .724 & & \\
\hline $\begin{array}{l}\text { 1. The majority of the shares in my family business are } \\
\text { owned by family members }\end{array}$ & .708 & .234 & \\
\hline $\begin{array}{l}\text { 4. In my family business, non-family managers and } \\
\text { directors are named by family members }\end{array}$ & .690 & .214 & \\
\hline $\begin{array}{l}\text { 14. In my family business, non-family employees are } \\
\text { treated as part of the family }\end{array}$ & & .808 & \\
\hline $\begin{array}{l}\text { 15. In my family business, contractual relationships are } \\
\text { mainly based on trust and norms of reciprocity }\end{array}$ & .202 & .805 & \\
\hline $\begin{array}{l}\text { 16. Building strong relationships with other institutions (i.e., } \\
\text { other companies, professional associations, government } \\
\text { agents, etc.) is important for my family business }\end{array}$ & .236 & .500 & \\
\hline $\begin{array}{l}\text { 25. Family owners are less likely to evaluate their } \\
\text { investment on a short-term basis }\end{array}$ & .107 & 0.210 & .777 \\
\hline
\end{tabular}




\begin{tabular}{llll}
\hline Items & \multicolumn{2}{c}{ Component } \\
\hline $\begin{array}{l}\text { 21. In my family business, affective considerations are } \\
\text { often as important as economic considerations }\end{array}$ & .175 & .759 \\
$\begin{array}{l}\text { 19. Protecting the welfare of family members is critical } \\
\text { to us, apart from personal contributions to the business }\end{array}$ & .246 & -.199 & .567 \\
\hline $\begin{array}{l}\text { Source: own calculations based on the survey data. } \\
\end{array}$
\end{tabular}

The first dimension, labeled family control and identification with the firm is composed of two aspects, that is family control and identification with the firm (11 items). Interestingly, Gast, Filser, Coen Richtering, Harms, Kraus, and Chang (in press) observed five causal configurations of the SEW dimensions and identified the presence of family control and identification with the firm in three of these causal paths. The second dimension, labeled binding social ties contains three items, i.e., building strong relationships with institutions, contractual relationships based on trust and norms of reciprocity, and treating non-family employees as the part of the family. And finally, the third dimension called emotional attachment of family members is composed of three items, namely: the likelihood to evaluate family owners' investments on a short-term basis, treating affective considerations as important economic considerations, and protecting the welfare of family members as crucial to owners, apart from personal contributions to the business.

\section{Control variables}

In order to preserve the analysis from the impact of exogenous factors, we used two control variables. Following previous studies (Chu, 2011) we assessed firm size using the total number of employees in the firm, and it was measured on a three-point scale - (1) the company is employing less than 9 employees; (2) the company is employing more than 10 but less than 49 employees, and (3) the company is employing more than 50 employees. Thus, the respondents were asked to categorize their business into one of three categories. Secondly, the firm's age was assessed, and in this regard respondents were asked an open-ended question about the number of years the company had operated in the market. The rationale for such a question relies on the assumption that more established companies have a higher reputation, are more experienced at sustaining in difficult market conditions, and have more opportunities to fulfill family obligations, related for example to family ownership. 


\section{RESULTS}

Table 2 shows the means, standard deviations, and correlations for the variables studied in the research project. It demonstrates there are small correlations between the studied constructs. In particular, competitive advantage is poorly correlated with the dimensions of SEW (family control and identification with a firm, binding social ties, and emotional attachment). However, all dimensions of SEW are mutually correlated. Firm age correlates positively with firm size and competitive advantage, as well as with binding social ties and emotional attachment. Firm size, in turn, correlates negatively with family control and identification with a firm, and with binding social ties.

Table 2. Means, standard deviations and correlations between dimensions of studied constructs and descriptive statistics $(n=193)$

\begin{tabular}{|c|c|c|c|c|c|c|c|}
\hline & Variables & 1 & 2 & 3 & 4 & 5 & 6 \\
\hline 1 & Age & - & & & & & \\
\hline 2 & Size & $.254 * *$ & - & & & & \\
\hline 3 & Competitive advantage & .130 & .051 & 1 & & & \\
\hline 4 & Family control and identification with a firm & .072 & $-.142 *$ & -.018 & 1 & & \\
\hline 5 & Binding social ties & $.161^{*}$ & $-.152 *$ & .023 & $.369 * *$ & 1 & \\
\hline \multirow[t]{3}{*}{6} & Emotional attachment & $.148^{*}$ & -.101 & .088 & $.488 * *$ & $.157^{*}$ & 1 \\
\hline & Mean & 17.26 & 1.6 & 4.14 & 5.72 & 4.92 & 4.97 \\
\hline & SD & 14.96 & 0.659 & 0.93 & 1.24 & 1.12 & 1.05 \\
\hline
\end{tabular}

Note: $\mathrm{n}=193,{ }^{*} \mathrm{p}<0,05,{ }^{* *} \mathrm{p}<0,01$

Source: own calculations based on the survey data.

To further test the relationships between SEW and competitive advantage, we used structural equation modeling in the MPlus 8.0 statistical package using a general type of the analysis stating that competitive advantage is a dependent variable related to SEW. In Table 3 we present the influence of SEW dimensions and control variables on competitive advantage of the family company.

In Table 3, Model 1 shows the effects of the control variables on the dependent variable - namely: competitive advantage. The subsequent Model 2 shows the effects of SEW dimensions and control variables on competitive advantage. Both models are well fitted with a root mean square error of approximation below the 0.08 cut-off line, and CFI and TLI indexes above the 0.900 cut-off level. 
Table 3. Relationships between SEW and competitive advantage

\begin{tabular}{|c|c|c|}
\hline \multirow{3}{*}{ Constant } & Model 1 (SE) & Model 2 (SE) \\
\hline & 0.615 & 0.558 \\
\hline & $(0.139) * * *$ & $(0.135)^{* * *}$ \\
\hline Size & $0.058(0.097)$ & $0.128(0.115)$ \\
\hline Age & $0.007(0.004)$ & $0.002(0.006)$ \\
\hline Family control and identification with a firm & - & $-0.280(0.156)^{*}$ \\
\hline Binding social ties & - & $0.150(0.214)$ \\
\hline Emotional attachment & - & $0.495(0.314)$ \\
\hline $\begin{array}{l}\text { Root Mean Square Error of Approximation } \\
\text { (RMSEA) (the lower the better) }\end{array}$ & 0.045 & 0.059 \\
\hline Compound Fit Index (CFI) (the higher the better) & 0.987 & 0.935 \\
\hline Tucker-Lewis Index (TLI) (the higher the better) & 0.979 & 0.922 \\
\hline
\end{tabular}

Analyses bring support for hypothesis 1 , while the family control and identification with a firm dimension of SEW explain competitive advantage, although the relationship is negative (Model 2 : $B=-0.280, p<0.1$ ). Contrary to most previous studies that have underlined the advantages of a family business in attenuating the agency problems due to reducing agency cost by the unclear separation between ownership and management (Lee and Chu, 2017, Zhou, Tam, and Yu, 2013), our results are analogous to the earlier concerns on the negative effect of family involvement in ownership, management and control (Naldi, Nordqvist, Sjolberg, \& Wiklund, 2007), especially the observation that family involvement is a barrier to attaining family business effectiveness (Hillier \& McColgan, 2009). Our findings, related to the other two SEW dimensions (binding social ties and emotional attachment), are counter to our theoretical presumption - these findings show similarity to the literature, in which relationships between family business features and firm effectiveness are not significant (Carney, Van Essen, Gedajlovic, \& Heugens, 2015). Therefore, as Carney et al. (2015) suggest, to fully understand the relationship between SEW and family business success or failure, key mediators should be taken into account. One of them could, for example, be familiness (Minichilli, Corbetta, \& MacMillan, 2010). In sum, SEW and competitive advantage are partially associated. 


\section{DISCUSSION AND CONCLUSION}

The results of the considerations have two important theoretical implications. First and foremost, they contribute to strategic management by providing new results of empirical research that emphasizes the importance of SEW as a strategic resource. Such wealth is a significant source of competitive advantage for the company. Building this resource is extremely complicated and, therefore, difficult to follow, which emphasizes its strategic value.

Secondly, it transpired that SEW is an important predictor of competitive advantage. Family businesses rely on more complex social dynamics than the dynamics of a pure market, where the informal sphere is critical to the realization of creative values. In addition to economic aspects, they include non-measurable and emotional aspects. In particular, the full effects of strategic actions launched around SEW are more nuanced and beyond direct effects. Focusing on the SEW components, we contribute to the list of determinants of competitive advantage, and in particular, how it is attained in family business settings. This will provide an enhanced understanding of the complex, strategic dynamics across different types of family firms triggered by SEW and competitive advantage. Our results clarify how family control and identification with a firm hinders the competitive advantage of family businesses. This highlights an area of possible interest in family business management professionalization.

Our research results also lead to recommendations for practitioners. In particular, the relationship between SEW and competitive advantage of a company is complex. In order to make better-informed, embedded, strategic choices, the activities of management should focus on three main areas: family control and identification with a firm, bonding social ties, and the emotional attachment of family members. Moreover, while the influence of family control and identification with a firm on competitive advantage is negative, we refer to the concept of family business professionalization (Lien \& Li, 2014). In particular, we argue that family business owners should entrust the management of the family firm to professional managers. Consequently, family members should focus more on the ownership aspects and formal control over the actions performed by professionals.

While the theory enriched in our study does not rely on idiosyncratic environment characteristics, future studies in other empirical settings could deepen the understanding of the generalizability of the results and also merit further discussion. Although our research results are not contingent upon firm size, we cannot be certain that the findings generalize towards large family businesses. In particular, we propose that a deeper understanding of 
the given relationships might be obtained by using Latent Profile Analysis, reflecting family business characteristics as latent classes.

In design terms, we encourage researchers to study processes and events with more dependent variables. Our argument is in line with Miller, Washburn and Glick's (2013) research, underlying that firm performance is a complex notion which contains multiple formative dimensions. Future research should examine the effects of SEW on family firm performance in terms of objective and subjective measures related to different constructs such as growth, value creation and capture, social effectiveness, high performance, wellbeing, etc. Additionally, we encourage scholars to test the predicting validity of the scales using different firm performance indicators (Frank, Kessler, Rusch, Suess-Reyes, \& Weismeir-Sommer, 2016).

To the best of our knowledge, only a few previous studies have addressed the SEW dimensions and their measurement. Gast et al. (2018) identified five dimensions congruent with the FIBER scale. Contrary to the aforementioned results, our empirical data show support for a three factor solution combined by family control and identification with the firm, binding social ties, and renewal of family bonds and emotional attachment of family members. Hauck, Suess-Reyes, Back, Prugl and Frank (2016) demonstrated the value of taking into account the shortened version of the FIBER scale (named REI scale) which contains only three dimensions of core affective endowments: renewal of family bonds, emotional attachment of family members, and identification of family members with the firm. Two dimensions of the FIBER scale, namely family control and influence and binding social ties are excluded because they do not pass the validation criteria and do not clearly capture the affective values a family derives from its ownership and control. Debicki, Kellermanns, Chrisman, Pearson, and Spencer (2016), in order to capture the firm performance effects of SEW, used the importance of the potential benefits of three dimensions - family prominence, family continuity, and family enrichment. In light of this evident confusion, we see a clear need for further empirical work aimed at refining the validity of socioemotional measurement. Future research may pursue the question about the multidimensionality of SEW.

Our theory is limited by not distinguishing the different types of family firms. James, Jennings and Breithereuz (2012) call for more research that investigates the heterogeneity with regards to different family structures, values, and interaction patterns. Randerson, Dossena, and Fayolle (2016) underline the importance of differences among families across cultures, legal systems and religions. Importantly, Souder, Zaheer, Sapienza and Ranucci (2017) note a contrast between two types of family firms, minority family ownership and majority family ownership, in the context of new technology 
adoption. Randolph, Li, and Daspit (2017) have blended family intention to pursue transgenerational succession and family ability to acquire external knowledge, and suggest four types of family firms labeled "constrained," "competency-enhancing," "diversified family dominant," and "dynastic." We, therefore, encourage the examination of SEW in different family business types as a fruitful avenue for future research.

The multidimensionality of SEW provides interesting nuances to this construct - on the one hand. However, on the other hand, configurations of socioemotional factors also highlight that they likely result in complex strategic decision-making processes (Deephouse \& Jaskiewicz, 2013). It is noteworthy that SEW dimensions may have a negative valence (Schultze \& Kellermanns, 2015) and may be in conflict with each other (Vardaman \& Gondo, 2014). Consistent with these arguments, Kellermanns et al. (2012) highlight the fact that SEW dimensions can have a negative or positive impact on firm performance. In this respect, Debicki et al. (2017) conclude their recent empirical findings that family prominence (reputation and social support within the community) and family continuity (the maintenance of family in the business) positively influence firm performance, but simultaneously found the negative impact of family enrichment (fulfilling a set of obligations towards the family at large).

Provided that interdependencies are depicted by discontinuity and equifinality, there is a fruitful avenue for future research on the basis of qualitative comparative analysis (Misangyi \& Acharya, 2014), thereby extending our ability to understand SEW more deeply. The configurational design has accommodated the complexity of firm performance (MacDougall, Bauer, Novicevic, \& Buckley, 2014) and equifinality (Fiss, 2011). For example, Gast et al. (2018) argue that individual SEW dimensions are not inherently negative or positive. They suggest five causal configurations of SEW dimensions, showing how their combined effects influence family firm innovativeness. Although it makes sense to theorize SEW dimensions as different variables since it has extensive theoretical and empirical support, it is particularly appropriate to understand SEW complexity, and future research should examine the appropriate configurations. The other noteworthy variation on qualitative comparative analysis is using a configural design in conjunction with meta-analysis (Joshi, Son, \& Roh, 2015).

The research results come with a number of limitations that stem mainly from the known shortcomings of quantitative research conducted with a survey method. The assessments of all the variables examined are based on the respondents' subjective opinions. This might cause a bias due to the respondents' tendency to reply positively to questions related to performance. The inclusion of objective measures could reinforce the 
conclusions of this study. Limitations are also connected with the fact that, in each respondent firm, only one manager evaluated enterprise performance. In order to decrease the risk of bias during the design and administration of our research, we assured respondent confidentiality. This is aimed at reducing common method bias by making respondents less likely to modify their answers due to social desirability or how they think others may expect them to answer.

Obviously, in future research, it is crucial to increase the number of respondents. Moreover, we can assume that the use of longitudinal analysis would be required to investigate the entire complexity of the relationships between SEW and competitive advantage. Future studies could also aim to determine how industry classification or industry size might bias the results. In further studies, it would be worthwhile to use other mediating variables, such as familiness, innovativeness, or moderating variables, such as task environment or organizational climate. It also seems reasonable to focus on the implications of SEW in the long run - especially using qualitative research. Future research in other countries should be undertaken in order to evaluate whether our results might be country-specific.

\section{References}

Anderson, R.C., \& Reeb, D.M. (2003). Founding-family ownership and firm performance: Evidence from the S\&P 500. The Journal of Finance, 58(3), 1301-1328. https://doi.org/10.1111/1540-6261.00567

Antoncic, B. \& Hisrich, R.D. (2001). Intrapreneurship: Construct refinement and cross-cultural validation. Journal of Business Venturing, 16(5), 495527. https://doi.org/10.1016/S0883-9026(99)00054-3

Bauweraerts, J., \& Colot, O. (2017). Exploring nonlinear effects of family involvement in the board of entrepreneurial orientation. Journal of Business Research, 70, 185-192. https://doi.org/10.1016/j. jbusres.2016.08.020

Berrone, P., Cruz, C., \& Gomez-Mejia, L.R. (2012). SEW in family firms: Theoretical dimensions, assessment approaches, and agenda for future research. Family Business Review, 25(3), 258-279. https://doi. org/10.1177/0894486511435355

Bettinelli, C., Sciascia, S., Randerson, K., \& Fayolle, A. (2017). Researching entrepreneurship in family firms. Journal of Small Business Management, 55(4), 506-529. https://doi.org/10.1111/jsbm.12347

Carney, M., Van Essen, M., Gedajlovic, E.R., \& Heugens, P. (2015). What do we know about private family firms? A meta-analytic review. Entrepreneurship Theory and Practice, 39(3), 513-544. https://doi. org/10.1111/etap.12054 
Cassia, L., De Massis, A., \& Pizzurno, E. (2011). An exploratory investigation of NPD in small family businesses from northern Italy. International Journal of Business, Management and Social Sciences, 2(2), 1-14.

Chrisman, J.J., \& Patel P.J. (2012). Variations in R\&D investments of family and non-family firms: Behavioral agency and myopic loss aversion perspectives. Academy of Management Journal, 55(4), 976-997. https:// doi.org/10.5465/amj.2011.0211

Chrisman, J.J., Chua, J.H., De Massis, F., Frattini, F., \& Wright, M. (2015). The ability and willingness paradox in family firm innovation. Journal of Product Innovation Management, 32(3), 310-318. https://doi. org/10.1111/jpim.12207

Chu, W. (2011). Family ownership and firm performance: Influence of family management, family control, and firm size. Asia Pacific Journal of Management, 28(4), 833-851. https://doi.org/ 10.1007/s10490-009-9180-1

Classen, N., Carree, M., Van Gils, A., \& Peters, B. (2014). Innovation in family and non-family SMEs: An Exploratory Analysis. Small Business Economics, 42(3), 595-609. https://doi.org/10.1007/s11187-013-9490-z

Corbett, A., Covin, J.G., O’Connor, G.C., \& Tucci, C.L. (2013). Corporate entrepreneurship: State-of-the-art research and future research agenda. Journal of Product Innovation Management, 30(5), 812-820. https://doi. org/10.1111/jpim.12031

Craig, J.B., Pohjola, M., Kraus, S., \& Jensen, S.H. (2014). Exploring relationships among proactiveness, risk-taking and innovation output in family and non-family firms. Creativity \& Innovation Management, 23(2), 199-210. https://doi.org/10.1111/caim.12052

De Massis, A., Kotlar, J., Chua, J.H., \& Chrisman, J.J. (2012). Family Business Studies: An Annotated Bibliography. UK: Edward Elgar Publishing.

De Massis, A., Kotlar, J., Frattini, F., Chrisman, J.J., \& Nordqvist, M. (2016). Family governance at work: Organizing for new product development in family SMEs. Family Business Review, 29(2), 189-213. https://doi. org/10.1177/0894486515622722

Debicki, B.J., Kellermanns, F.W., Chrisman, J.J., Pearson, A.W., \& Spencer, B.A. (2016). Development of the SEW importance (SEWi) scale for family business research. Journal of Family Business Strategy, 7(1), 47-57. https://doi.org/10.1016/j.jfbs.2016.01.002

Debicki, B.J., Van de Graaff Randolph, R.V., \& Sobczak, M. (2017). SEW and family firm performance: A stakeholder approach. Journal of Managerial Issues, 29(1), 82-111.

Deephouse, D.L., \& Jaskiewicz, P. (2013). Do family firms have better reputation than non-family firms? An integration of SEW and social identity theories. Journal of Management Studies, 50(5), 337-360. https://doi.org/10.1111/joms.12015

Drasgow, F. (1984). Scrutinizing psychological tests: Measurement equivalence and equivalent relations with external variables are the central issues. 
Psychological Bulletin, 95(1), 134-135. http://doi.org/10.1037/00332909.95.1.134

Duran, P., Kammerlander, N., van Essen, M., \& Zellweger, T. (2016). Doing more with less: Innovation input and output in family firms. Academy of Management Journal, 59(4), 1224-1264. https://doi.org/10.5465/ amj.2014.0424

Durand, R., Grant, R.M., \& Madsen, T.L. (2017). The expanding domain of strategic management research and the quest for integration. Strategic Management Journal, 38(1), 4-16. https://doi.org/10.1002/smj.2607

Evert, R.E., Martin, J.A., McLeod, M.S., \& Payne, G.T. (2015). Empirics in family business research. Progress, challenges, and the path ahead. Family Business Review, 29(1), 17-43. https://doi. org/10.1177/0894486515593869

Fan, G. H., \& Zietsma, C. (2017). Constructing a shared governance logic: The role of emotions in enabling dually embedded agency. Academy of Management Journal, 60(6), 2321-2351. https://doi.org/10.5465/ amj.2015.0402

Filser, M., Brem, A., Gast, J., Kraus, S., \& Calabrò, A. (2016). Innovation In Family Firms - Examining The Inventory And Mapping The Path. International Journal of Innovation Management, 20(6), 1-39. https://doi.org/10.1142/ S1363919616500547

Fiss, P.C. (2011). Building better causal theories: A fuzzy set approach to typologies in organization research. Academy of Management Journal, 54(2), 393-420. https://doi.org/10.5465/amj.2011.60263120

Frank, H., Kessler, A., Rusch, T., Suess-Reyes, J., \& Weismeier-Sammer, D. (2016). Capturing the familiness of family businesses: Development of the family familiness scale (FIFS). Entrepreneurship Theory and Practice, 41(5), 709-742. https://doi.org/10.1111/etap.12229

Gast, J., Filser, M., Coen Rightering, J.P., Harms, R., Kraus, S., \& Chang, M-L. (2018). SEW and Innovativeness in Small and Medium-Sized Family Enterprises: A Configuration Approach. Journal of Small Business Management, 56(S1), 53-67. https://doi.org/10.1111/jsbm.12389

George, B.A. (2011). Entrepreneurial orientation: Theoretical and empirical examination of the consequences of differing construct representations. Journal of Management Studies, 48(6), 1291-1313. https://doi. org/10.1111/j.1467-6486.2010.01004.x

Gomez-Mejia, L.R., Campbell, J.T., Martin, G., Makri, M., Sirmon, D.G., \& Hoskisson, R.E. (2014). SEW as mixed gamble: Revisiting family firm R\&D investments with the behavioral agency model. Entrepreneurship Theory and Practice, 38(6), 1351-1374. https://doi.org/10.1111/etap.12083

Gomez-Mejia, L.R., Cruz, C., Berrone, P., \& De Castro, J. (2011). The bind that ties: SEW preservation in family firms. Academy of Management Annals, 5(1), 653-707. https://doi.org/10.1080/19416520.2011.593320

Gomez-Mejia, L.R., Hynes, K.T., Nunez-Nickel, M., \& Moyano-Fuentes, H. (2007). SEW and business risk in family-controlled firms: Evidence from 
Spanish olive oil mills. Administrative Science Quarterly, 52(1), 106-137. https://doi.org/10.2189/asqu.52.1.106

Gomez-Mejia, L.R., Makri, M., \& Lazzara-Kitana, M. (2010). Diversification desictions in family controlled firms. Journal of Management Studies, 47(2), 223-252. https://doi.org/10.1111/j.1467-6486.2009.00889.x

Hauck, J., and Prugl, R. 2015. Innovation activities during intra-family leadership succession in family firms: An empirical study from a SEW perspective. Journal of Family Business Strategy, 6(2), 104-118. https:// doi.org/10.1016/j.jfbs.2014.11.002

Hauck, J., Suess-Reyes, J., Beck, S., Prugl, R., \& Frank, H. (2016). Measuring the SEW in family-owned and managed firms: A validation and short form of FIBER scale. Journal of Family Business Strategy, 7(3), 133-148. https://doi.org/10.1016/j.jfbs.2016.08.001

Hayton, J.C., \& Kelley, D.J. (2006). A competency-based framework for promoting corporate entrepreneurship. Human Resource Management, 45(3), 407-427. https://doi.org/10.1002/hrm.20118

Hillier, D., \& McColgan, P. (2009). Firm performance and managerial succession in family managed firms. Journal of Business Finance \& Accounting, 36(34), 461-484. https://doi.org/10.1111/j.1468-5957.2009.02138.x

Hinkin, T.R. (1998). A brief tutorial on the development of measures for use in survey questionnaires. Organizational Research Methods, 1, 104-121. https://doi.org/10.1177/109442819800100106

James, A. E., Jennings, J. E., \& Breitkreuz, R. S. (2012). Worlds apart? Rebridging the distance between family science and family business research. Family Business Review, 25(1): 87-108. https://doi. org $/ 10.1177 / 0894486511414271$

Jones, C.D., Makri, M., \& Gomez-Mejia, R.M. (2008). Affiliate directors and perceived risk bearing in publicly traded, family-controlled firms: The case of diversification. Entrepreneurship Theory and Practice, 32(6), 1007-1026. https://doi.org/10.1111/j.1540-6520.2008.00269.x

Joshi, A., Son, J., \& Roh, H. (2015). When can women close the gap? A metaanalytic test of sex differences in performance and rewards. Academy of Management Journal, 58(5), 1516-1545. https://doi.org/10.5465/ amj.2013.0721

Kabbach de Castro, L.R., Aguilera, R.V., \& Crespi-Cladera, R. (2017). Family firms and compliance: Reconciling the conflicting predictions within the SEW perspective. Family Business Review, 30(2), 137-159. https://doi. org/10.1177/0894486516685239

Kammerlander, N., \& Ganter, M. (2015). An attention-based view of family firm adaptation to discontinuous technological change: Exploring the role of family CEOs' noneconomic goals. Journal of Product Innovation Management, 32(3), 361-383. https://doi.org/10.1111/jpim.12205

Kellermanns, F.W., Eddleston, K.A., \& Zellweger, T. (2012). Extending the SEW perspective: A look at the dark side. Entrepreneurship Theory and Practice, 36(6), 1175-1182. https://doi.org/10.1111/j.1540-6520.2012.00544.x 
Konig, A., Kammerlander, N, \& Enders, A. (2013). The family innovator's dilemma: How family influence affects the adoption of discontinuous technologies by incumbent firms. Academy of Management Review, 38(3), 418-441. https://doi.org/10.5465/amr.2011.0162

Kraiczy, N.D., Hack, A. \& Kellermanns, F.W. (2014). New product portfolio performance in family firms. Journal of Business Research, 67(6), 10651073. https://doi.org/10.1016/j.jbusres.2013.06.005

Lee, T., \& Chu, W. (2017). The relationship between entrepreneurial orientation and firm performance: Influence of family governance. Journal of Family Business Strategy, 8(4), 213-223. https://doi.org/10.1016/j. jfbs.2017.09.002

Leitterstorf, M.P., \& Rau, S.B. (2014). SEW and Ipo underpricing of family firms. Strategic Management Journal, 35(5), 751-760. https://doi. org/10.1002/smj.2236

Levenburg, N.M., Schwarz, T.V., \& Almallah, S. (2002). Innovation: A recipe for success among family-owned firms in West Michigan? Seidman Business Review, 8(1), 21-22.

Lien, Y.-Ch., Li, S. (2014). Professionalization of family business and performance effect. Family Business Review, 27(4), 346-364. https://doi. org/10.1177/0894486513482971

Lumpkin, G.T., Brigham, K.H., \& Moss, T.W. (2010). Long-term orientation for the entrepreneurial orientation and performance of family business. Entrepreneurship and Regional Development, 22(3/4), 241-264. https:// doi.org/10.1177/0894486513508980

MacDoughall, A.E., Bauer, J.E., Novicevic, M.M., \& Buckley, M.R. (2014). Toward the pattern-oriented approach to research in human resources management: A review of configurational and category theorizing, methods, and applications. Research in Personnel and Human Resources Management, 32, 177-240.

Mahto, R.V., Ahluwalia, S., \& Khanin, D. (2014). Psychological ownership of family firm successors: A conceptual approach. Small Business Institute Journal, 10(2), 65-76.

Miller C.C., Washburn N.T., \& Glick W.H. (2013). The myth of firm performance. Organization Science, 24(3), 948-964. https://doi.org/10.1287/ orsc.1120.0762

Miller, D., \& Le Breton-Miller, I. (2014). Deconstructing SEW. Entrepreneurship Theory \& Practice, 38, 713-720. https://doi.org/10.1111/etap.12111

Miller, D., Le Breton-Miller, I., \& Lester, R.H. (2010). Family ownership and acquisition behavior in publicity-traded companies. Strategic Management Journal, 31(2), 201-223. https://doi.org/10.1002/smj.802

Miller, D., Le Breton-Miller, I., \& Scholnick, B. (2008). Stewardship vs. stagnation: An empirical comparison of small family and non-family businesses. Journal of Management Studies, 45(1), 51-78. https://doi. org/10.1111/j.1467-6486.2007.00718.x 
Miller, D., Le Breton-Miller, I., Lester, R.H., \& Cannella Jr., A.A. (2007). Are family firms really superior performers? Journal of Corporate Finance, 13(5), 829-858. https://doi.org/10.1016/j.jcorpfin.2007.03.004

Minichilli, A., Corbetta, G., \& MacMillan, D.C. (2010). Top management teams in family-controlled companies: Familiness, faultlines, and their impact on financial performance. Journal of Management Studies, 47(2), 205222. https://doi.org/10.1111/j.1467-6486.2009.00888.x

Misangyi, V.F., \& Acharya, A.G. (2014). Substitutes or complements? A configurational examination of corporate governance mechanisms. Academy of Management Journal, 57(6), 1681-1705. https://doi. org/10.5465/amj.2012.0728

Mohr, A., \& Puck, J. (2013). Revisiting the trust-performance link in strategic alliances. Management International Review, 53(2), 269-289. https:// doi.org/10.1007/s11575-012-0145-0

Naldi, L., Nordqvist, M., Sjolberg, K., \& Wiklund, J. (2007). Entrepreneurial orientation, risk taking, and performance in family firms. Family Business Review, 20(1), 33-47. https://doi.org/10.1111/j.1741-6248.2007.00082.x

O'Boyle, E.J., Pollack, J.M., \& Rutherford, M.W. (2012). Exploring the relation between family involvement and firms' financial performance: A metaanalysis of main and moderator effects. Journal of Business Venturing, 27(1), 1-18. https://doi.org/10.1016/j.jbusvent.2011.09.002

Randerson, K., Dossena, G., \& Fayolle, A. (2016). The futures of family business: Family entrepreneurship. Futures, 75, 36-43.

Randolph, R.V., Li, Z., \& Daspit, J.J. (2017). Toward a typology of family firm corporate entrepreneurship. Journal of Small Business Management, 55(4), 530-546. https://doi.org/10.1111/jsbm.12342

Reilly, T.M., \& Jones III, R. (2017). Mixed methodology in family business research: Past accomplishments and perspectives for the future. Journal of Family Business Strategy, 8(3), 185-195. https://doi.org/10.1016/j. jfbs.2017.08.003

Rothausen, T.J. (1999). "Family" in organizational research: A review and comparison of definitions and measures. Journal of Organizational Behavior, 20(6), 817-836. https://doi.org/10.1002/(SICl)10991379(199911)20:6<817::AID-JOB953>3.0.CO;2-E

Salvato, C., Chirico, F., \& Sharma, P. (2010). A farewell to the business: Championing exit and continuity in entrepreneurial family firms. Entrepreneurship and Regional Development, 22(3-4), 321-348. https:// doi.org/10.1080/08985621003726192

Schulze, W.S., \& Kellermanns, W.F. (2015). Reifying SEW. Entrepreneurship Theory and Practice, 39(3), 447-459. https://doi.org/10.1111/etap.12159

Sharma, P., \& Sharma, S. (2011). Drivers of proactive environmental strategy in family firms. Business Ethics Quarterly, 21(2), 309-334. https://doi. org/10.5840/beq201121218

Shepherd, D., \& Haynie, J.M. (2009). Family business, identity conflict, and an expedited entrepreneurial process: A process of resolving identity 
conflict. Entrepreneurship Theory and Practice, 33(6), 1245-1264. https://doi.org/10.1111/j.1540-6520.2009.00344.x

Songini, L., \& Gnan, L. (2015). Family involvement and agency cost control mechanisms in family small and medium-sized enterprises. Journal of Small Business Management, 53(3), 748-779. https://doi.org/10.1111/ jsbm.12085

Sorenson, R.L., Goodpaster, K.E., Hedberg, P.R., \& Yu, A. (2009). The family point of view, family social capital, and firm performance: An exploratory test. Family Business Review, 22(3), 239-253. https://doi. org $/ 10.1177 / 0894486509332456$

Souder, D., Zaheer, A., Sapienza, H., \& Ranucci, R. (2017). How family influence, SEW, and competitive conditions shape new technology adoption. Strategic Management Journal, 38(9), 1774-1790. https://doi. org/10.1002/smj.2614

Spriggs, M., Yu, A., Deeds, D., \& Sorenson, R.L. (2013). Too many cooks in the kitchen: Innovative capacity, collaborative network orientation, and performance in small family businesses. Family Business Review, 26(1), 32-50. https://doi.org/10.1177/0894486512468600

Stevens, C.E., Kidwell, R.E., \& Sprague, R. (2015). Bound by laws, or by values? A multi-level and cross-national approach to understanding the protection of minority owners in family firms. Corporate Governance: An International Review, 23(3), 203-215. https://doi.org/10.1111/ corg.12089

Strike, V.M., Berrone, P., Sapp, S.G., \& Congiu, L. (2015). A SEW approach to CEO career horizons in family firms. Journal of Management Studies, 52(4), 555-583. https://doi.org/10.1111/joms.12123

Sullivan, D.M., \& Ford, C.M. (2010). The alignment of measures and constructs in organizational research: The case of testing measurement models of creativity. Journal of Business and Psychology, 25(3), 505-521. http://doi. org/10.1007/s10869-009-9147-8

Uhlaner, L.M. (2006). Business family as a team: Underlying force for sustained competitive advantage. In P. Poutziouris, K.X. Smyrnios, \& S.B. Klein (Eds.), Handbook of Research on Family Business (pp. 125-144). Cheltenham, England: Edward Elgar.

Vardaman, J.M., \& Gondo, M.B. (2014). SEW conflict in family firms. Entrepreneurship Theory and Practice, 38(6), 1317-1327. https://doi. org/10.1111/etap.12126

Wagner, D., Block, J.H., Miller, D., Schwens, C., \& Xi, G. (2015). A meta-analysis of the financial performance of family firms: Another attempt. Journal of Family Business Strategy, 6(1), 3-13. https://doi.org/10.1016/j. jfbs.2015.01.001

Welsh, D.H.B. Memili, E., Rosplock, K., Roure, J., \& Segurado, J.L. (2013). Perceptions of entrepreneurship across generations in family offices: A stewardship theory perspective. Journal of Family Business Strategy, 4(3), 213-226. https://doi.org/10.1016/j.jfbs.2013.07.003 
Zhou, J., Tam, O.K., \& Yu, P. (2013). An investigation the role of the family ownership, control and management in listed Chinese firms. Asian Business \& Management, 12(2), 197-225. https://doi.org/10.1057/ abm. 2012.40

\begin{abstract}
Abstrakt
Obecnie badacze coraz częściej skupiaja się na zrozumieniu w jaki sposób firmy rodzinne osiqgajq przewage nad konkurencjq, choć $w$ tych dociekaniach czasem pomijane sq wyjqtkowe cechy odróżniajqqce od siebie firmy rodzinne i nierodzinne. $W$ niniejszym artykule zakładamy, iż bogactwo społeczno-emocjonalne może uruchamiać albo wręcz ograniczać inicjatywy strategiczne w firmach rodzinnych, które to inicjatywy ostatecznie kształtujq ich przewagę konkurencyjnq. Dlatego też w prezentowanych badaniach przeprowadzonych w 193 polskich firmach dociekamy, w jaki sposób bogactwo spoteczno-emocjonalne i przewaga konkurencyjna firmy sq powiqzane w kontekście firm rodzinnych. Jak wskazujq wyniki naszych badań, bogactwo społeczno-emocjonalne i przewaga konkurencyjna sq częściowo powiqzane, a samo bogactwo społeczno-emocjonalne może być uznane za ważnq determinante wyników uzyskiwanych przez organizacje.
\end{abstract}

Słowa kluczowe: przedsiębiorczość rodzinna, bogactwo społeczno-emocjonalne, przewaga konkurencyjna.

\title{
Biographical notes
}

Katarzyna Bratnicka-Myśliwiec holds a Ph.D. in Management from the University of Economics in Katowice where she currently works as Assistant Professor in the Department of Entrepreneurship and Management Innovation. Her research is focused on entrepreneurship, innovation, organizational creativity, and the SEW of family businesses. She is the author and co-author of over 40 scientific works including journal articles, student textbooks, and monographic books.

Martyna Wronka-Pośpiech holds a Ph.D. in Management from the University of Economics in Katowice where she currently works as Assistant Professor in the Department of Entrepreneurship and Management Innovation. Her research is focused on entrepreneurship, innovation and strategic management in the social and public sectors. Focusing mainly on social entrepreneurship and entrepreneurship, in general, she is the author and co-author of over 60 scientific works including journal articles, student textbooks, and monographic books.

Tomasz Ingram holds a Ph.D. in Management from the University of Economics in Katowice where he currently works as Associate Professor in the Department of Entrepreneurship and Management Innovation. His research 
is focused on entrepreneurship, innovation, human resource management, and the organizational resilience of family businesses. Focusing mainly on human resource management and entrepreneurship intersection he is the author and co-author of over 100 scientific works including journal articles, student textbooks, and monographs. 